\title{
The Effect of Work Satisfaction on Employee Performance in General and Protocol Section of Regional Secretariat of Luwu Regency
}

\author{
Imran', Muhammad Aqsa ${ }^{2}$, Sapar $^{3}$ \\ \{imran@student.umpalopo.ac.id, muhammadaqsa@umpalopo.ac.id, sapar@umpalopo.ac.id\} \\ Postgraduate of Management, Universitas Muhammadiyah Palopo \\ Jalan Jendral Sudirman Km. 3. Binturu Kota Palopo, 91922, Indonesia
}

\begin{abstract}
This study aimed to determine the effect of job satisfaction on employee performance in the general and protocol section of Regional Secretariat of Luwu Regency. This research applied a quantitative approach with expost facto research design. The population of the study was 75 employees which taken by random technique in the General and Protocol Section of Regional Secretariat of Luwu Regency, which was carried out by distributing questionnaires and documentation. Data analysis techniques were analyzed by using simple linear regression analysis. The results shows that job satisfaction had a significantly positive effect on employee performance. Employee performance in the general and protocol section of Regional Secretariat of Luwu Regency can be done by increasing and building employee job satisfaction.
\end{abstract}

Keywords: job satisfaction, employee performance

\section{Introduction}

Job satisfaction is the hope of everyone who has worked. Job satisfaction expresses a number of matches between a person's expectations about his work which can be in the form of work performance given by an organization or institution for the results of his work. Different levels of satisfaction according to the value that each employee believes. A large number of fields in work must be based on the wishes and needs of the employees to get higher satisfaction or vise versa

Therefore, job satisfaction achieved by every employee is inseparable from good performance because performance is an important aspect in organization. The performance of employees is very important because the low performance of both individuals and groups will have a significant impact on an institution or organization. Performance according to[1] can be defined as a form of work that is produced in quantity and quality that can be achieved by an employee to carry out the tasks based on the authority given to them. If human resources perform superior, then the vision and mission and goals of an institution or organization will also be good, or vice versa.

Employee performance can be measured when supported by a number of work achievements that can be use to to various tasks given by superiors suitable with the specified time and can be fulfilled every target set in the organization. Mangkunegara[2] explain that performance is a set of work performance or work results in quantity or quality obtained by an employee to perform the duties based on the commitments and obligations. According [3] work is the amount or advantage obtained from the income given by someone who does the work when the work is done. While 
According to[4] explain that performance is the result or level of success obtained by a person in a certain period of time to carry out tasks that can be compared with various possibilities that can occur. Someone who is successful in doing work is able to manage the work based on the size, goals or targets, predetermined standards for mutually agreed.

The demand for high employee performance has become part of every institution or organization in providing a service to the community. Therefore, community satisfaction in terms of providing the best services such as fast service, not convoluted and ethical culture is inseparable from good employee performance.

\section{Literature Review}

According to [5] explain "Kepuasan kerja adalah sikap emosional yang menyenangkan dan mencintai pekerjaannya". Job satisfaction in activities is perceived satisfaction in doing work to improve work results, assignments, awards, equipment and conditions of a conducive work environment. Job satisfaction outside of activity is the satisfaction that can be felt by employees outside of work with the level of income that will be obtained from the work result, to fulfill the needs. [6] states that "Kepuasan kerja (job satisfaction) adalah suatu perasaan positif tentang pekerjaan, yang dihasilkan dari suatu evaluasi dari karakteristik-karakteristiknya". According to Luthans[7], job satisfaction has the following indicators:

a) The job itself is related to the characteristics of the work and the difficulty of the work being carried out is fun and satisfying and provides challenges to employees.

b) Income/salary is the amount of money that is earned as a reward and is considered as a thing, which is considered feasible compared to organizations where there is a human element. Salary paid in cash is a reward received periodically or with a fixed period, for example once a month.

c) Promotion opportunity is the policy of a company to provide job opportunities that are changed in the level of authority and higher accountability so that it causes the authority and responsibilities that have been given in the previous time, therefore given the opportunity for progress in an organization.

d) Supervision is the condition or control of a direct superior to employees.

e) Coworkers are partners who work in one company and the relationship is in the form of collaborated work

\subsection{The performance}

[8] explain employee performance is the result of quality and quantity work by an employee in carrying out their duties based on the authority given to them. $\left.{ }^{[9}\right]$ states that performance refers to the level of income that serves to create a job for employees. Performance illustrates how quickly employees complete the requirements of a job. Employee performance can be individual, because each employee has to be independent so it can makedifferences in completing their duties. The management department can assess employees for their work performance based on the performance of each employee [10]. 
Job Satisfaction has a relationship with emotional work performance that excites and loves the job. Job satisfaction in every job must be lived in work by getting satisfactory work results, placement, rewards, equipment and a good working environment. Employees who have extra work will feel the satisfaction obtained by a number of rewards received based on their work to get their needs. Job satisfaction will be achieved if the employee's needs are fulfilled for the work they do. A positive emotional attitude is created from job satisfaction that can create feelings of pleasure over the work carried out so it can produce experiences. High employee performance will increase high job satisfaction because their organizations pay attention to the rights of their employees.

From the explanation above, it can be described the conceptual framework of research as follows :

\begin{tabular}{|l|l|}
\hline Job Satisfaction (X) & Employee Performance (Y) \\
The job itself, & a) Quantity of Results; \\
a) Income/Salary, & b) Quality of Results; \\
b) Promotional Opurtunities, & c) Timeliness of Results; \\
c) Supervision, & d) Presence; \\
d) Co-Workers. & e) Abily to Work Together \\
Source : (Luthans, 2006) & Source: Mathis and Jackson (2006) \\
& \\
\hline
\end{tabular}

Fig.1. Conceptual Framework

\section{Method}

This research was analyzed with a quantitative approach with ex post facto research design. The population of the study was 75 employees taken randomly in the General and Protocol Section of the Regional Secretariat of Luwu Regency which was carried out using questionnaire, observation and documentation techniques. Data analysis techniques were analyzed by using simple linear regression analysis with the help of SPSS 22.0 computer software.

\section{Result And Discussion}

The results of this study try to analyze the effect of job satisfaction, employee performance in the general and protocol section of Regional Secretariat of Luwu Regency. The processed data can be seen in the table below:

Table 1. Coefficients ${ }^{\mathrm{a}}$ 


\begin{tabular}{ccccccc}
\hline \multirow{2}{*}{ Model } & \multicolumn{2}{c}{$\begin{array}{c}\text { Unstandardized } \\
\text { Coefficients } \\
\end{array}$} & \multicolumn{2}{c}{$\begin{array}{c}\text { Standardized } \\
\text { Coefficients } \\
\text { B }\end{array}$} & $\mathrm{t}$ & Sig. \\
\hline \multirow{2}{*}{1} & (Constant) & 20.757 & 2.302 & & 9.016 & .000 \\
& Job Satisfactiona & .063 & .105 & .070 & .599 & .551 \\
\hline
\end{tabular}

a.

Dependent Variable: Employee Performance

Based on the calculation results in the coefficient table above with a significance level of 0,000 . Therefore the results of testing in simple linear regression results obtained $\mathrm{Y}=20,757+0.063 \mathrm{X}+$ e show that job satisfaction has a relationship with employee performance variables with a constant value (a) of 20.757. The constant of 20.757, implies that the consistent value of the $\mathrm{Y}$ variable is 20.757, and the regression direction coefficient of 0.063 explains each addition of $1 \%$ of the $X$ value, then the $\mathrm{Y}$ value increases by 0.063 . The coefficient of the regression direction shows a positive value, so it can be stated that the direction of the effect of variable $\mathrm{X}$ on the variable $\mathrm{Y}$ is positive

Table 2. Model Summary

\begin{tabular}{llllll}
\hline Model & $\mathrm{R}$ & R Square & Adjusted R Square & $\begin{array}{l}\text { Std. Error of the } \\
\text { Estimate }\end{array}$ \\
\hline 1 & $.892^{\mathrm{a}}$ & .754 & .769 & 1.272 & \\
\hline
\end{tabular}

b. Predictors: (Constant), Job Satisfaction

Based on these calculations the coefficient of determination (Adjusted R2) is obtained that is 0.769. Means the magnitude of the variable employee satisfaction in the general section and protocele of the Luwu district secretariat that can be explained by the performance variable is 76.9 percent while the remaining 23.1 percent is influenced by other factors.

The results of the study above are not in line with the results of the study[11] also shows that job satisfaction is positively influenced by wages. This finding has been corroborated by many researchers[12],[13],[14]. [15] concluded that the salary system was the only motivating factor for employees in the car industry.

\section{Conclusion}

Based on the research results, it can be concluded that there is an effect of job satisfaction on performance. This is in line with several previous research findings which state that job satisfaction felt by employees in an organization will improve employee performance.

\section{Acknowledgments}

Dr. Muhammad Aqsa, S. Kom. M. Si., For knowledge and guidance so that this article can be finished. 


\section{Reference}

[1] Abuhashesh, M., Al-Dmour, R., \& Ed Masa'deh, R. '. (2019). Factors that affect Employees Job Satisfaction and Performance to Increase Customers' Satisfactions. Journal of Human Resources Management Research, 2019, 23. https://doi.org/10.5171/2019.354277

[2] Arnold, J.; Cooper, C.L.; Robertson, I. T. (1998). Work Psychology: Understanding Human Behaviour in the Workplace.3rd ed. Pearson Education: Prentice Hall http://www.google.co.in/url?url=http://www.uk.sagepub.com/ millward/files/slides/Introduction references.doc retrieved on April 8, 2015.

[3] Aziri, B. (2011). Job Satisfaction, a Literature Review. Management Research and Practice, 3(1), 77 90 .

[4] Carroll, S, Keflas, R. dan Watson, C. (1964). Kepuasan Kerja dan Produktivitas, Irwin: Illinois.

[5] David, F, Joseph dan William, K. (1970). Komitmen kepuasan kerja, Irwin: Illions.

[6] Vaishali, S., \& Ms.Jyotsna, S. (2015). Job Satisfaction and Job Performance: Linkages in Real World. Journal of Management Engineering and Information Technology, 2(2), 37-44.

[7] Febriyana, W. (2015). Pengaruh Kepuasan Kerja Terhadap Kinerja Karyawan PT. Kabepe Chakra 2015. E-Proceeding of Management, 2(3), 1-8.

[8] Hoppock, R. (1935). Kepuasan kerja. New York: Happer and Brothers.

[9] Luthans, F. (2005). Perilaku organisasi. Yogyakarta: Andi.

[10] Mangkunegara, A. P. (2011a). Manajemen Sumber Daya Manusia Perusahaan. Edisi Kesepuluh. Bandung : PT Remaja Rosdakarya.

[11] Mangkunegara, A. P. (2011b). Manajemen Sumber Daya Manusia Perusahaan. Edisi Kesepuluh. Bandung: PT Remaja Rosdakarya.

[12] Nguyen, at el. 2003. Job autonomy and job satisfaction: new evidence

[13] Cappelli \& Sherer, 1988. Satisfaction, Market Wages, \& Labor Relations: An Airline Study

[14] Brown, at el. 2008 A Meta-Analysis of Relationships Linking Employee Satisfaction to Customer Responses

[15] Kathawala, (1990), “An Investigation into Effects of ISO 9000 on Participants' Attitudes and Job Performance", Production and Inventory Management Journal, Second Quarter 


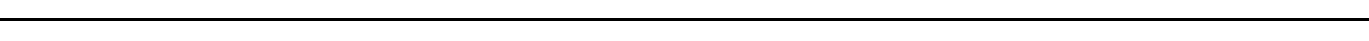

